\title{
Career adaptability and entrepreneurial behaviour in the K-12 classroom
}

Neto, Roque; Rodrigues, Vinicius Picanco; Polega, Meaghan; Persons, Megan

Published in:

Teachers and Teaching: Theory and Practice

Link to article, DOI:

10.1080/13540602.2018.1526783

Publication date:

2019

Document Version

Peer reviewed version

Link back to DTU Orbit

Citation (APA):

Neto, R., Rodrigues, V. P., Polega, M., \& Persons, M. (2019). Career adaptability and entrepreneurial behaviour in the K-12 classroom. Teachers and Teaching: Theory and Practice, 25(1), 90-109.

https://doi.org/10.1080/13540602.2018.1526783

\section{General rights}

Copyright and moral rights for the publications made accessible in the public portal are retained by the authors and/or other copyright owners and it is a condition of accessing publications that users recognise and abide by the legal requirements associated with these rights.

- Users may download and print one copy of any publication from the public portal for the purpose of private study or research.

- You may not further distribute the material or use it for any profit-making activity or commercial gain

- You may freely distribute the URL identifying the publication in the public portal 


\section{Career Adaptability and Entrepreneurial Behaviour in the K-12 Classroom}

\section{ROQUE DO CARMO AMORIM NETO ${ }^{*}$}

Given Name: Roque do Carmo

Family Name: Amorim Neto

aCollege of Urban Education, Davenport University. 6191 Kraft Ave. Grand Rapids, MI 49512 ,

USA. Phone: 616.544.5063. E-mail: roque.neto@ davenport.edu

\section{VINICIUS PICANCO RODRIGUESb}

Given Name: Vinicius

Family Name: Picanco Rodrigues

b Section of Engineering Design and Product Development, Department of Mechanical

Engineering, Technical University of Denmark. Produktionstorvet, Building 426, 2800 -

Kgs.Lyngby, Denmark. Phone: +45 452541 53. E-mail: vipiro@dtu.dk

\section{MEAGHAN POLEGAc}

Given Name: Meaghan

Family Name: Polega

cCollege of Urban Education, Davenport University. 6191 Kraft Ave. Grand Rapids, MI 49512, USA. Phone: 989.205.1796. E-mail: mpolega1 @ davenport.edu

\section{MEGAN PERSONS ${ }_{d}$}

Given Name: Megan

Family Name: Persons

dCollege of Urban Education, Davenport University. 6191 Kraft Ave. Grand Rapids, MI 49512, USA. Phone: 616.581.4014. E-mail: mpersons@davenport.edu

* Correspondence concerning this article should be addressed to Roque do Carmo Amorim Neto College of Urban Education, Davenport University. 6191 Kraft Ave. Grand Rapids, MI 49512, USA. Phone: 616.544.5063. E-mail: roque.neto@davenport.edu

Funding: This work was supported by the M.E. Davenport Foundation, M.E. Davenport Legacy Endowment Fund [grant project: Advancing a Research Agenda on Teacher Education]. 


\section{Abstract:}

With data from 311 K-12 public school teachers working in the United States, we tested a predictive model of entrepreneurial behaviour that included demographic characteristics and career adaptability, and identified differences between highly and minimally entrepreneurial teachers on how and why they adapt their teaching practices. Statistical analysis identified education and career adaptability to predict entrepreneurial behaviour. Qualitative analysis revealed that highly entrepreneurial teachers considered their professional development and the broader school system, while teachers scoring low on entrepreneurial behaviour focused on behaviour management and coping with imposed regulations when adapting their practices. The discussion includes theoretical and practical implications.

Keywords: career adaptability; entrepreneurship; demographic characteristics; teachers

\section{Introduction}

While the study of entrepreneurial behaviour, especially across disciplines, is relatively new, the word "entrepreneur" has been in use for centuries (Landstrom, 1999). Sometime in the early eighteenth century, Irish banker Richard Cantillon (1680-1734) formally introduced entrepreneurship as a concept in business and economics, and the economic movement that followed established the importance of equilibrium, uncertainty, and risk (Carlsson et al., 2013; Murphy, Liao, \& Welsch, 2006). Still, classical economic theory did little to "emphasise the entrepreneurial function in the economy" (Carlsson et al., 2013, p. 916). Thus, it was not until the United States became a major industrial power that a focus on entrepreneurship truly reemerged in the economic field (Carlsson et al., 2013). 
In the first half of the twentieth century, entrepreneurial research was largely marketdriven. At that point, research began shifting away from the assumption that entrepreneurial behaviours were solely economic, and moved toward analysis of such behaviours in a multitude of human and behavioural science fields (Carlsson et al., 2013; Murphy et al., 2006). The 1980s and 1990s, in particular, marked an increased interest in entrepreneurial research and education (Carlsson et al., 2013; Katz, 2003). Journals and courses focusing on the entrepreneur began to emerge. Many of those offerings extended to fields outside of the business world, most notably agriculture, engineering, arts and science, as well as psychology, technology, public policy, and politics (Katz, 2003; Murphy et al., 2006). As a result, the idea of a social entrepreneur-one who demonstrates entrepreneurial behaviour in pursuit of a social goal — appeared as a field of study in the early 2000s (Carlsson et al., 2013).

Within the larger field of social entrepreneurship lies the education discipline. The first entrepreneurship course was taught in 1947. Since then, thousands more courses have emerged (Katz, 2003). While the preponderance of entrepreneurial education occurred and still occurs in business schools, there has been an increased demand in other markets, including education. It is important to note, however, that there is a difference between entrepreneurial education (i.e. the teaching of entrepreneurship and its associated components) and entrepreneurship in education (i.e. the employment of entrepreneurial behaviours in classroom settings).

Entrepreneurship in education has been the focus of two recent studies (Chand, 2014; Omer Attali \& Yemini, 2016). This focus has led to the emergence of teachers as entrepreneurs. One can easily find terms such as "edu-preneur" and "teacherpreneurship" in the literature (Davis, 2009; Foote, 2012). While from a theoretical perspective it is assumed that teachers who engage in entrepreneurial behaviour are more likely to adapt their work practices (van Dam, 
Schipper, \& Runhaar, 2010), little empirical evidence has been produced to demonstrate how and why they do so. Therefore, our research aims to identify any differences between highly and minimally entrepreneurial teachers regarding how and why they adapt their teaching practices. In addition, this study aims to test a predictive model of entrepreneurial behaviour. This model includes demographic characteristics and career adaptability.

\section{Theoretical background}

\subsection{Entrepreneurship}

It is widely accepted across disciplines that entrepreneurial behaviour is not only highly desirable, but also necessary as a means of impacting organizational vitality and growth. As such, many definitions of "entrepreneurship" exist within and across these disciplines. According to Hebert and Link (1989), an entrepreneur is one who "specialises in taking responsibility for and making judgmental decisions that affect the location, the form, and the use of goods, resources, or institutions" (p. 47). Similarly, van Dam et al. (2010) define entrepreneurial behaviour as behaviour involving the recognition of opportunities and the coordination of resources to act upon those opportunities. More broadly, Borasi and Finnigan (2010) define an entrepreneur as one who can translate knowledge into educational, financial, or communal value. Petersen (2014) explains that an entrepreneur is one who creates an organization that has a profound impact on the lives of others. Perhaps most simply, however, Stevenson (2004) defines entrepreneurship as "the pursuit of opportunity beyond the resources you currently control" (p. 3).

Given that entrepreneurship is studied from a variety of disciplinary perspectives — and to varying degrees within those fields - it is difficult to assign a singular definition. However, it is clear from the literature that entrepreneurship — as studied in economics, marketing, finance, 
business management, psychology, sociology, public policy, and education-is grounded in the exploration and exploitation of opportunity. Furthermore, opportunity recognition, initiative, and risk management are important elements of entrepreneurial behaviour across each of these disciplines (Rauch \& Frese, 2000). In one large meta-analysis of entrepreneurial research, Carlsson et al. (2013) expand upon Rauch and Frese's research, identifying five related components relevant to the definition and theory of entrepreneurship as a whole: "risk, uncertainty, innovation, perception, and change" (p. 915). According to the authors, these five elements impact nearly all aspects of entrepreneurial activities and are therefore universal. In conjunction with this idea, Shane and Venkataraman (2000) argue that the sources of opportunities, the processes by which those opportunities are enacted, and the individuals who exploit them are critical to all fields of entrepreneurial research.

Initial examination of entrepreneurship relied on a trait-based perspective. According to this school of thought, stable and innate characteristics predict entrepreneurial behaviour. From this viewpoint, an entrepreneur is born with a set of characteristics rather than developing them with training and over time (Chell, 1985; Zhang et al., 2009).

More recent literature, however, suggests that successful entrepreneurs likely learn a set of entrepreneurial competencies - knowledge, aptitudes, and skills — that directly contribute to the sustainment of an organization (van Dam et al., 2010). Unlike a more traditional trait-based approach, this competency-based approach relies on the assumption that entrepreneurial behaviours can, in fact, be developed in an individual. Furthermore, these competencies are believed to be recognizable and assessable, likely making the competency-based approach more advantageous (AUTHOR, 2017a; Hayton \& Kelley, 2006; van Dam et al., 2010). This paper therefore adopts the competency-based perspective. 


\subsubsection{Entrepreneurship in Education}

In education, teachers must act as entrepreneurs, rather than simply as deliverers of instruction. According to van Dam et al. (2010), teachers must be entrepreneurial when they design lessons, use new technologies in the classroom, and secure funding for a variety of projects they do in their classrooms. This entrepreneurial behaviour can ensure that teachers respond to the ever-changing field of education to best serve the needs of students. Van Dam et al. (2010) outline a variety of implications that arise when teachers engage in entrepreneurial behaviour. Teachers who exhibit entrepreneurial behaviour identify opportunities, innovate, and take risks. Additionally, these teachers network with other teachers, think creatively, and exhibit high levels of career adaptability.

Van der Kuip and Verheul (2003) suggest that a core competency of entrepreneurship is the ability to seek out opportunities in one's career. Onstenk (2003) specifically focused research on teachers and collected data from 25 teachers. These teachers generated lists of behaviours possessed by teachers who are entrepreneurs; the lists included the ability to "take chances and act upon them" (p. 84). To be able to take chances, teachers must identify an opportunity when it presents itself. These chances may come in a daily lesson, or perhaps in continuing their education.

After these opportunities have been identified, entrepreneurial teachers respond to them. In their review of entrepreneurship research, Guth and Ginsberg (1990) found that the ability to innovate, respond to change, and take the initiative is characteristic of organizations that promote entrepreneurship. These characteristics can be extrapolated to entrepreneurial individuals. Teachers must come up with new and innovative ideas, and make changes to both curriculum and daily teaching. Additionally, teachers who are entrepreneurs are able to take the initiative in 
a situation. Antoncic and Hisrich (2001) and Frese, Fray, Hillburger, Leng and Tag (1997) show the importance of taking initiative as a critical element in being proactive, an essential component of good teaching.

By identifying opportunities and responding to them, teachers may also be taking risks. Entrepreneurial individuals not only take risks; they are also comfortable in taking those risks. Rauch and Frese (2000) state that successful entrepreneurs take risks in a calculated manner. Entrepreneurial teachers take risks in the classroom, whether this involves trying a new method of delivering content to their students, or trying a new form of technology in the classroom. Gibb (1998) also explains that this is a characteristic of strong entrepreneurs.

\subsubsection{Predictors of Entrepreneurial Behaviour}

In trying to identify predictors of entrepreneurship, researchers have explored characteristics such as age, education, gender, and work experience. In some cases, they found patterns, while in others the findings are conflicting. Regarding gender, studies systematically found gender differences, with women generally exhibiting less entrepreneurial behaviour than men (Georgellis \& Wall, 2005; Kelley, Singer \& Herrington, 2012; Maes, Leroy, \& Sels, 2014; Mueller \& Conway Dato-on, 2013). Studies have also found that the higher the educational level of an individual, the higher the likelihood of this individual engaging in entrepreneurial behaviour (AUTHOR, 2017a; Ertuna \& Gurel, 2011). However, other studies have not found education to be a direct predictor of entrepreneurial behaviour (van Dam et al., 2010). When it comes to age and work experience, findings are even more conflicting. For example, while Hatak, Harms, and Fink (2015) identified that the older workers get, the less inclined they are to engage in entrepreneurial behaviours. On the other hand, Thorgren, Sirén, Nordström, and 
Wincent (2016) found no difference between younger and older individuals in their intention of engaging in entrepreneurship.

Moving beyond demographic characteristics as predictors of entrepreneurial behaviour, van Dam et al. (2010) conducted a study with teachers in the Netherlands to determine which competencies would predict entrepreneurial behaviour among teachers. The study found that creative thinking, networking and teamwork skills, entrepreneurial climate, and career adaptability predicted entrepreneurial behaviour. Career adaptability was found to be one of the strongest predictors of entrepreneurial behaviour.

\subsection{Career Adaptability}

Career adaptability was introduced as a theoretical framework for conceptualizing how adults adjusted to the challenges of, and changes within, the work world (Super \& Kidd, 1979; Super \& Knasel, 1979; Super \& Knasel, 1981). Savickas (1997) expanded upon this construct as a means of qualifying how individuals cope with vocational changes throughout the course of their careers. As a way of explicating these individual adaptations, Savickas (2005) defined career adaptability as a concept that refers to the "psychological construct that denotes an individual's readiness and resources for coping with current and imminent vocational development tasks, occupational transitions, and personal traumas" (p. 51). Similarly, Rottinghaus, Buelow, Matyja, and Schneider (2012) report that career adaptability embodies a person's level of comfort with work-related assignments, ability to manage and make use of change, and capacity to recover when unexpected events occur that modify one's career plans. Applied to the teaching profession, career adaptability could indicate how teachers change professions, or simply change school districts or grade levels. It may also be how teachers change their lesson plans to better serve the needs of their students. 
A body of studies has demonstrated that career adaptability has an impact on workrelated outcomes such as entrepreneurship, promotability, work competency, job satisfaction, and work performance (Almahamid, McAdams, \& Kalaldeh, 2010; Rottinghaus, Day, \& Borgen, 2005; Rudolph, Lavigne, \& Zacher, 2017; Savickas, Briddick, \& Watkins, 2002). Consider, for example, the study conducted by Savickas et al. (2002), which surveyed 200 college students in the United States. Their results suggest that career development is related to one's ability to make adjustments based on his or her surroundings. The authors state that "high competence means that individuals are sufficiently knowledgeable to apply occupational information to self" (p. 29). A person who can adapt to a variety of situations must also have a high knowledge of content, so they are able to apply their knowledge to different situations. Consider also the study conducted by Almahamid et al. (2010) with 91 companies included among the Listed Manufacturing Companies in the Amman Stock Exchange. The goal of their study was to measure employees' levels of career adaptability and job satisfaction. They found a significant relationship between career adaptability and job satisfaction.

These studies illustrate the rapid growth of research on career adaptability, as noted by Rudolph et al. (2017). While this body of research has yet to be systematically reviewed and integrated, there are noticeable gaps in the literature about the use of career adaptability in the K12 teaching profession. Much of the research and discussion around the concept has centered on its use in the private sector.

2.3. Contributions to the literature and the field

This research is driven by three main questions:

(i) To what extent does career adaptability contribute to entrepreneurial behaviour among $\mathrm{K}-12$ teachers? 
(ii) Which demographic characteristics are correlated with teachers' entrepreneurial behaviour?

(iii) How and why do highly and minimally entrepreneurial teachers adapt their teaching practices?

With the aim of addressing these questions, this study provides several contributions to the literature and the field of entrepreneurship in education. First, this research provides additional empirical evidence on the extent to which career adaptability predicts teachers' entrepreneurial behaviour. The investigation of such a potential relationship supports a superior understanding of the entrepreneurial behaviour phenomenon among teachers. At the same time, it underpins the future establishment of policies targeted at career development in different levels of the educational system.

Second, this study investigates which demographic characteristics (i.e. age, educational background, gender, grade level taught, and years of teaching experience) exert influence on teachers' entrepreneurial behaviour. This investigation extends and complements the findings on the influence of demographic characteristics on entrepreneurial behaviour, which has been carried out in the literature, and more specifically by AUTHOR (2017a, 2017b).

Third, by examining how and why highly and minimally entrepreneurial teachers adapt their teaching practices, a deeper inquiry is developed in regards to practical aspects of entrepreneurial behaviour in the teaching profession. The qualitative aspect of this question allows us to better explore practical and tangible aspects of career adaptability. It also permits highlighting the main differences between highly and minimally entrepreneurial teachers. Furthermore, through a better understanding of how adaptability unfolds among teachers in practical terms, the design of policies aimed at fostering both career adaptability and 
entrepreneurial behaviour in the educational context is strengthened.

\section{Methods}

\subsection{Procedures and participants}

We sent an online survey to 371 public school teachers working in the United States of America and teaching in any grade from kindergarten to 12th grade. The message sent informed potential participants of the goal of the study and reminded them of their right to decline participation in the study or to stop responding to it at any time. The message also ensured that the identity of those participating in the study would remain anonymous. In addition, potential participants were reminded that after completing the survey they could enter a drawing for one of four US \$50 gift cards.

A total of 311 teachers completed the survey (response rate $=84 \%$ ). Most of the participants were female $(n=229,73.6 \%)$ and had a graduate degree $(n=190,61.1 \%)$. The gender distribution and the education level of the participants are similar to the overall teacher

population of the United States. As reported by the U.S. Department of Education, National Center for Education Statistics (2016) in 2015, $76 \%$ of public school teachers in the United States were women and $56 \%$ had a master's or higher degree. The mean age was 42.3 years ( $S D$ $=11.7)$ and the mean of teaching experience was 14.3 years $(S D=9.9)$.

\subsection{Measures}

\subsubsection{Demographics}

Participants were asked about their age, educational background, gender, grade level taught, and years of teaching experience.

\subsubsection{Open-ended questions}


Participants were also asked to list up to three ways they had adapted their teaching in the past academic year, and to explain what they were trying to achieve by making those adaptations.

\subsubsection{Entrepreneurial behaviour}

The instrument developed by van Dam et al. (2010) was used to assess entrepreneurial behaviour. Among the 14 items used were items such as "I kept a close eye on new developments in the educational field" and "I usually waited to see how things worked out". Chronbach's alpha was 0.84 .

\subsubsection{Career adaptability}

Career adaptability was assessed by the 11 -item instrument developed by Rottinghaus et al. (2005). Example items include: "I can overcome potential barriers that may exist in my career" and "I enjoy trying new work-related tasks". Chronbach's alpha was 0.85 .

\subsection{Analyses}

This study uses a concurrent nested mixed methods approach (Hanson, Creswell, Plano Clark, Petska, \& Creswell, 2005). As Creswell and Plano Clark (2007) elucidate, mixed methods are appropriate to address a set of research questions that quantitative or qualitative methods alone cannot address. In the specific case of concurrent nested mixed methods, the two types of data (quantitative and qualitative) are collected and analysed at the same time (Hanson et al, 2005). This is the case with this study, as all the measures were given at once through the online survey as described above.

\subsubsection{Quantitative analyses}

To identify the predictors of entrepreneurial behaviour, a regression analysis was performed. The predictive model included the demographic information and career adaptability. 
For the categorical variables of gender (female and male) and educational background (undergraduate and graduate degrees), one category was selected as reference and the other was used as dummy. For gender, "female" was used as the reference category, and for educational background "graduate degree" was used as the reference category.

We calculated the Chronbach's alpha to determine the internal consistency reliability of the career adaptability and the entrepreneurial behaviour scales. Descriptive statistics were used to calculate frequencies, averages, and correlations. They were also used to identify the participants in the top and the bottom $10 \%$ with regards to entrepreneurship scores.

\subsubsection{Qualitative analyses}

Three members of the research team conducted thematic analysis. According to Braun and Clarke (2006), "Thematic analysis is a method for identifying, analyzing and reporting patterns (themes) within data" (p. 79). Our analysis was inductive, as the identified themes emerged directly from the data with no attempt to fit the emerging themes into a theoretical frame (Braun \& Clarke, 2006). Furthermore, our data had abundant commonalities and recurrent themes, which was appropriate for thematic analysis (Eisenhardt \& Graebner, 2007).

Qualitative research credibility and trustworthiness was gained through triangulation methods, which is a way to show research rigor and verification (Greckhamer \& KoroLjungberg, 2005). Specifically, we used investigator triangulation. Investigator triangulation can be achieved when two or more researchers conduct the data analysis (Elliott, Fischer, \& Rennie, 1999). In this study, three members of the research team coded the data separately and held several meetings to discuss and compare coding notes, emerging themes and representative quotes, until reaching agreement in all elements.

\section{Results}


This study had two main goals. The first was to identify the predictors of entrepreneurial behaviour $(M=3.55, S D=0.46)$ by assessing a series of variables that included age $(M=42.34$, $S D=11.70)$, educational background, gender, years of teaching experience $(M=14.34, S D=$ 9.93), and career adaptability $(M=4.07, S D=0.47)$. The second goal was to explore the differences in the ways highly and minimally entrepreneurial teachers adapt their teaching and the reasons why they do so.

\subsection{Quantitative results}

To achieve the first goal of this study, a regression analysis was conducted. The study variables' intercorrelation values are presented in Table 1. Career adaptability and educational background were positively correlated with entrepreneurial behaviour. Therefore, only these two variables were included in the subsequent regression analysis.

Table 1

Intercorrelations of variables

\begin{tabular}{llllll}
\hline Variable & 1 & 2 & 3 & 4 & 5 \\
\hline 1. Age & & & & & \\
2. Career adaptability & .06 & & & & \\
3. Education & .08 & .07 & & & \\
4. Entrepreneurial behaviour & .07 & $.46^{*}$ & $.13^{*}$ & & \\
5. Gender & .04 & .04 & -.00 & .03 & .01 \\
6. Teaching experience & $.81^{*}$ & .03 & $.13^{*}$ & .05 & .01 \\
\hline
\end{tabular}

Note. ${ }^{*} p<.05 . N=311$.

The results of the regression analyses indicate that both career adaptability $(\beta=.45, p<$ $.001)$ and education $(\beta=.10, p<.05)$ have significant contributions to the prediction of entrepreneurial behaviour. These results suggest that teachers who were more likely to adapt their teaching practices and careers displayed higher entrepreneurial behaviour, and that teachers 
with higher levels of education were more likely to show higher entrepreneurial behaviour. The proportion of the variance in entrepreneurial behaviour $\left(R_{2}=.22\right)$ that is explained by career adaptability and education is $22 \%$.

To achieve the second goal of this study, one quantitative step was taken. This step was calculating averages to identifying the participants in the top $10 \%(\mathrm{M}=4.46, \mathrm{SD}=0.208)$ and in the lower $10 \%(M=2.88, S D=0.281)$ in regards to their entrepreneurial behaviour scores. Each group comprised 31 participants.

\subsection{Qualitative results}

Once the highly and minimally entrepreneurial participants were identified, thematic analysis revealed how and why teachers have adapted their teaching, as well as the differences between the two groups.

Asked about what they have done to adapt their teaching, participants in both groups said they have adapted assessment, time management, teaching strategies, curriculum, peer collaboration, and technology. In addition to these adaptations common to the two groups, the top $10 \%$ group also mentioned fostering student collaboration, seeking professional training and knowledge acquisition opportunities, and aligning their practice to policies, standards and regulations. Exclusive to the bottom 10\% were changes in behaviour management, differentiating instruction and lesson plans, and reducing expectations for lower achieving students. Table 2 shows the adaptations presented by both groups side by side and a few representative quotes for illustration.

Asked why they adapted their teaching, the highly and the minimally entrepreneurial teachers both identified drivers such as students, teachers, teaching practices, and school. Regarding students as the main reason to adapt their teaching, both groups shared the same 
goals: achieve student success, facilitate learning, increase student engagement, and meet students' needs. But when it came to teachers, teaching practice, and schools as drivers for adapting, the groups had significant differences in terms of goals. When presenting teachers as drivers, the top $10 \%$ aimed to increase collaboration with peers and further develop teachers professionally, while the bottom $10 \%$ explained they were motivated by personal reasons and previous professional training and experiences. The drivers pertaining to teaching practice were use of data to drive instruction for the top $10 \%$, and behaviour management for the bottom $10 \%$. As for school as a driver of the changes they made in their teaching, the highly entrepreneurial teachers wanted to address differences with administration and respond to the lack of resources. The minimally entrepreneurial ones reported that their goal was to respond to imposed decisions. Both groups also reported that their changes were driven by the goal of managing limited time. Finally, only the top $10 \%$ mentioned policy as a driver, with the goal of adhering to plans, goals, and standards established by the school, the district, the state, and the federal Department of Education. Table 3 shows side by side the drivers and specific goals presented by both groups and a few representative quotes for illustration.

\section{Discussion}

The objectives of this study encompassed quantitatively testing a predictive model of entrepreneurial behaviour that included demographic characteristics and career adaptability, and qualitatively investigating any differences on how and why teachers adapt teaching practices between the groups with high and low scores on entrepreneurial behaviour. The quantitative results show that career adaptability predicts entrepreneurial behaviour among teachers. Moreover, the demographic variable of educational background was also associated with teachers' entrepreneurial behaviour. Teachers with graduate degrees scored significantly higher 
on entrepreneurial behaviour than teachers holding only undergraduate degrees. The demographic variables of age, gender, and years of teaching experience have not indicated a statistically significant influence on teachers' entrepreneurial behaviour. In the qualitative analyses, key differences emerged between the top 10\% (highly entrepreneurial teachers) and the bottom $10 \%$ (minimally entrepreneurial teachers) on how and why they adapt teaching practices. These qualitative aspects will be discussed further in this section.

The finding that career adaptability predicts teachers' entrepreneurial behaviour is consistent with what van Dam et al. (2010) reported. The authors found that teachers more flexible in terms of adapting their career trajectories and work responsibilities displayed higher levels of entrepreneurial behaviour. Because entrepreneurial activities are fundamentally subjected to a wide array of intense changes and challenges, adaptability seems to be a very important characteristic of entrepreneurial individuals. Adaptability is an essential factor for coping with the constantly changing environment in the educational system as a whole, from individual classrooms to the broader national and international contexts.

Entrepreneurial teachers tend to be more satisfied with their jobs (AUTHOR, 2017a), at the same time that higher levels of career adaptability have also been shown to create higher levels of job satisfaction in other areas of work (Almahamid et al., 2010). Teachers' job satisfaction, in turn, produces several positive effects in areas such as student engagement and achievement, educational outcomes, and teacher retention (Hoekstra, 2014; Kitchel et al., 2012; Song \& Mustafa, 2015). Therefore, designing policies and strategies aimed at developing teacher's career adaptability helps educational institutions to positively influence educational outcomes. Moreover, these institutional policies on career adaptability should also develop teachers' ability to process and act upon information emerging from their classrooms with a view 
to re-planning and adapting to new working conditions. Such policies and strategies should be designed and operationalised with the main objective of providing teachers with the fundamental resources to cope with their vocational, occupational, and personal developments, in line with what Savickas (2005) put forth in the very definition of career adaptability.

Within such a context, the four dimensions of career adaptability resources defined by Savickas and Porfeli (2012)—concern, control, curiosity, and confidence — might prove to be a useful framework to support the development of institutional policies on teachers' career adaptability. Focused training sessions and workshops could initially target planning exercises and techniques for the educational professional (i.e. "concern"), coupled with scenario planning methods and strategic (long-term) thinking tools. In direct connection, teachers could then be offered proper capacitation in self-discipline — such as disciplined learning and working techniques - in order to develop a sense of organization, autonomy and order (i.e. "control").

Furthermore, the "curiosity" aspect should be ensured in terms of allowing teachers to freely explore new dimensions of their teaching capabilities and their school's own infrastructure. In general, this exploration could lead to better use of resources, increased efficiency and efficacy, and innovative developments in the classroom. In particular, allowing benchmarking against organizations in different cultural environments would substantially add to the exploration aspects of career adaptability. Finally, the "confidence" portion might be achieved by minimizing judgmental and hypercritical attitudes and embracing a more collaborative working environment, with effective performance measurement mechanisms. Such a "confidence" aspect could directly foster the development of higher teacher self-efficacy, which is also reported to influence entrepreneurial behaviour positively (AUTHOR, 2017b). 
In regards to the demographic variables, educational background was the only one having a positive significant contribution to teachers' entrepreneurial behaviour. This result is also consistent with the literature. AUTHOR (2017a) also found that teachers with specialization and master's degrees showed increased levels of entrepreneurial behaviour when compared against their peers with only bachelor's or high school degrees. Within such a context, it is important to call attention to the complementary finding by van Dam et al. (2010) that educational background is significantly correlated with entrepreneurial knowledge. Furthermore, the rise of entrepreneurial training for teachers is externally driven by the need to effectively address students' needs and provide them with role models for the increasingly demanded entrepreneurial behaviour. Along those lines, educational programs have been increasing their focus on developing an entrepreneurial skill set to foster students' abilities to think creatively, deal with scarce resources, and improve learning outcomes (Ali, Topping, \& Tariq, 2009; Aurini, 2004; AUTHOR, 2017a; Fairbanks et al., 2010; Foote, 2012; Webber \& Scott, 2008).

As these new demands pose significant challenges to teachers' training and education, universities are increasingly recognizing the benefits of going beyond the dissemination of entrepreneurship concepts among teachers, and embracing the development of an entrepreneurial culture (AUTHOR, 2017a; Ortega \& Bagnato, 2015). With that, teachers with advanced degrees display a higher probability of being exposed to elements of entrepreneurship during their academic careers. This fact is also supported by the growing body of entrepreneurship-related content that has become widely available in graduate programs from different fields of knowledge (AUTHOR, 2017a). In turn, this higher exposure may be materialised in the classroom and translated into a higher entrepreneurial attitude towards teaching. Finally, a 
growing body of evidence in the literature establishes the positive correlation between education and overall entrepreneurial success (Dickson, Solomon, \& Weaver, 2008).

Unexpectedly, no statistically significant difference was found for any of the other demographic characteristics examined (i.e. age, gender, or years of teaching experience). This finding was rather unanticipated, as it contradicts some of the findings reported in the literature. Age and years of experience are tightly connected, and age is often used as a proxy for work and life experience. Even though there is no agreement on how age influences entrepreneurial behaviour, differences between age groups are consistently reported. It might be that more experienced teachers show increased entrepreneurial attitude due to their superior mechanisms for innovating in teaching practices and ampler access to resources (AUTHOR, 2017b; Kautonen, Hatak, Kibler, \& Wainwright, 2015; Weber \& Schaper, 2004).

Contrarily, researchers have found that older people tend to invest considerably less time in activities with ambiguous returns, such as the ones entrepreneurs typically encounter (Fung, Lai, \& Ng, 2001; Hatak et al., 2015). However, the teachers' innovation space does not necessarily involve increased risk levels or highly unclear activities. In this sense, schools and other educational organizations might operate as safe environments for teachers to innovate and experiment with new practices (AUTHOR, 2017b). The higher entrepreneurial behaviour displayed by older teachers might be interpreted as an expression of the wider range of experiences and personal mechanisms they possess in order to act upon entrepreneurial opportunities in the classroom.

Regarding gender, researchers of different nationalities and cultural backgrounds have demonstrated that women are generally less entrepreneurial, as has also previously been pointed out in the theoretical background. Potential environmental and institutional barriers, ingrained 
stereotypes based on masculine figures, and lack of self-efficacy are among the main factors behind the gender difference in entrepreneurial behaviour (Ahl, 2006; Langowitz \& Minniti, 2007; Lewis; 2006; Marlow \& Patton, 2005; Zhang et al., 2009). However, in a recently conducted study (AUTHOR, 2017b), researchers have not found significant differences between U.S.-based male and female teachers in regards to entrepreneurial behaviour.

Another line of thought for explaining the lack of gender differences is related to the exposure to a solid entrepreneurial culture in the U.S. In this regard, a more equal distribution of scores for entrepreneurial behaviour could be reasonably expected in the U.S. entrepreneurial environment (AUTHOR, 2017b). Besides, combining the fact that about approximately $56 \%$ of teachers in the U.S. have graduate degrees with the context of a female-dominated profession, leads to an alternative likely explanation for the lack of significant differences between male and female teachers (U.S. Department of Education, National Center for Education Statistics National Center for Education Statistics, 2016). A majority of U.S. teachers are women and a majority of those are more educated, which, as discussed, correlates to a more entrepreneurial attitude.

Open-ended questions on how and why teachers adapted their practices brings relevant insights into the mechanisms of teaching adaptation and the particular aspects it entails. In particular, by clustering teachers into two different groups (high and low scores in entrepreneurial behaviour), the different strategies, motivations, and procedures behind their adaptation practices become truly evident. Prompted with the request for listing up to three ways in which they adapted their teaching practices, teachers in both groups displayed a reasonably well-established connection to technology use and several classroom-related dimensions (e.g. 
adaptations of specific assessments, time management, curriculum changes, and overall teaching strategies).

The high availability of low-cost technological resources with reduced barriers to adoption (e.g., Google Docs and other free online tools) boosts the use of technology in the classroom, and its adaptation to students' needs, as also pointed out by van Dam et al. (2010). Furthermore, the aspects of formal assessment, time management, curriculum changes, and several other adaptations in teaching methods might present teachers with low-risk, high-return opportunities to improve their students' learning outcomes (i.e. "low-hanging fruit"). Coupling the exploitation of small changes in teaching strategies with a more ubiquitous and opportunistic use of technological resources may enable teachers to increase students' attention, focus, and retention.

Another important commonality between the two groups is the apparent perceived benefits of peer collaboration and curriculum changes. Even though these two aspects require a supposedly higher amount of effort to be achieved, they are still contained within the boundaries of the classroom or the educational institution, two spheres in which the majority of teachers might have a stronger influence and a higher sense of comfort in which to act. In particular, collaboration between peers could be a good source of relevant cross-content adaptations which, in turn, can foster a multidisciplinary perspective among students. Along those lines, stronger peer collaboration might potentially evolve into long-lasting curricular changes and impacts, from which students permanently benefit. This is particularly relevant because teamwork has been found to predict entrepreneurial behaviour (van Dam et al., 2010). More peer collaboration can lead to more entrepreneurship, which can foster the development of a more customised learning process. 
Specific only to the top 10\% group, three aspects emerged: (i) development of student collaboration, (ii) search for opportunities for professional training and knowledge acquisition, and (iii) alignment with broader external policies, standards, and regulations.

Teachers in the bottom $10 \%$ affirmed that they were adapting through (i) changes in behaviour management, (ii) differentiation of instruction methods and lessons plans, and (iii) reduction of expectations for low-achieving students. When directly comparing the adaptations put forth by the two groups, a difference of scope becomes evident: while the bottom $10 \%$ is mainly focused on matters within the classroom boundaries, the top $10 \%$ concentrated their attention on a broader, overarching system level.

In particular, highly entrepreneurial teachers demonstrated a more pronounced concern with general educational and regulatory trends, going beyond the scope of their own classrooms. This attention to the educational system that goes beyond their classroom daily duties also indicates the exercise of leadership. According to Gardner (2013), leaders consider the larger organization, and impact others beyond established boundaries. The literature has shown that when teachers act beyond their usual sphere of influence, they can bring about changes that impact school-wide curriculum, parents, the community, and sometimes even school district and state policies (Stivers \& Cramer, 2009). With their attention focused on the external world, teachers are better equipped to appropriately distill systemic trends into actionable plans within their educational environment. This is important because for decades school districts across the country have made investments to prepare their teachers to exercise leadership, whether formally or informally (Boyd-Dimock \& McGree, 1995; Danielson, 2007). In this sense, programs geared toward developing teacher leadership could also take entrepreneurship into consideration as part of their efforts. 
As to why teachers adapted their instructional practices, the two groups commonly reported several drivers: (i) addressing students' needs and fostering their success, (ii) teacher perspectives, (iii) their own teaching practices, and (iv) the schools. Both groups shared a genuine concern with learning outcomes, reporting a strong focus on engaging students and going to great lengths to meet their specific needs. Regarding their own perspectives as teachers, the top $10 \%$ heavily emphasised collaboration with peers as a driver, whereas the bottom $10 \%$ interestingly pointed to personal reasons and what they learned from previous professional experience. It is likely that highly entrepreneurial teachers see collaboration within the frame of their broader systemic view. Collaborating with other teachers across disciplines and institutions might be one of the first consistent steps towards a more systemic view. On the other hand, the group of teachers scoring low on entrepreneurial behaviour pointed to aspects such as work-life balance (i.e. family-related issues) and the use of resources acquired in summer courses.

Again, the classroom dimension was emphasised by the bottom 10\% group, who focused on the classroom as a major element of their teaching practice perspective. Teachers in this group highlighted the behaviour of their students as an important driver, along with the need of adjusting their expectations, and all related changes that would be required in the classroom. Within the same driver, the top $10 \%$ reported a richer use of data to support their teaching practice. In this sense, it seems that highly entrepreneurial teachers are inclined to look more closely at what data has to tell and therefore tend to sponsor efforts for collecting, processing, and interpreting data at different levels of the educational system. Highly entrepreneurial teachers seem to reflect and act in the light of new evidence.

At the school level as a driver, minimally entrepreneurial teachers demonstrated a more reactive attitude towards responding to imposed decisions. Therefore, the adaptation carried out 
by this group of teachers was an exogenous element, coming from school leadership and/or other authorities. On the other end of the spectrum, the top $10 \%$ adopted a more pronounced proactive posture in their responses. In particular, highly entrepreneurial teachers reported the will to clear differences and misunderstandings with administration, and to respond effectively to the lack of resources affecting their teaching, thereby acting as entrepreneurs themselves (van Dam et al., 2010).

The differences between the two groups can be traced back to the overall characteristics of entrepreneurial behaviour. Highly entrepreneurial individuals have developed the ability to identify the lack of resources with a view to adapting and setting goals accordingly or seeking out the needed resources, as opposed to simply not doing something or not carrying out a project/idea due to the lack of appropriate means (Sarasvathy, 2001; Sarasvathy, Dew, Velamuri, \& Venkataraman, 2010). Within such a context and having the school as a driver, only the top $10 \%$ group reported the adherence to plans, goals and standards defined by different organizations at different levels of the educational system (i.e. school, district, state, federal government, etc.). Once again, the broader systemic perspective of highly entrepreneurial teachers becomes apparent.

Some limitations of this study's setup can be discussed. First, despite the performance of an approach based on mixed methods, the qualitative portion of the research was based only on extracting condensed information on how and why teachers adapt teaching practices. Second, aspects of the schools' organizational climate were not addressed in the proposed predictive model. Third, since the research was carried out with U.S.-based teachers, the findings might be limited to their national reality.

With a view both to addressing these limitations and further developing the field of 
adaptability in educational entrepreneurship, future research streams could potentially point towards (i) investigating other qualitative aspects of teachers' adaptability further, based for example on in-depth interviews and/or wider questionnaire-based methods; (ii) embedding aspects of organizational climate and culture in the predictive model in order to assess how these aspects influence adaptability; (iii) comparing results and main findings across different cultural and national backgrounds.

\section{References}

Ahl, H. (2006). Why research on women entrepreneurs needs new directions. Entrepreneurship: Theory and Practice, 30(5), 595-621.

Ali, A., Topping, K. J., \& Tariq, R. H. (2009). Entrepreneurial inclinations of prospective teachers. New Horizons in Education, 56(2), 1-16.

Almahamid, S., McAdams, A. C., \& Kalaldeh, T. (2010). The relationships among organizational knowledge sharing practices: An empirical investigation of the listed manufacturing companies in Jordan. Interdisciplinary Journal of Information, Knowledge, and Management, 5(1), 337-356.

Antoncic, B., \& Hisrich, R. D. (2001). Intrapreneurship: Construct refinement and cross-cultural validation. Journal of Business Venturing, 16(5), 495-527.

Aurini, J. (2004). Educational entrepreneurialism in the private tutoring industry: Balancing profitability with the humanistic face of schooling. The Canadian Review of Sociology and Anthropology, 41(4), 475-491.

AUTHOR. (2017a).

AUTHOR. (2017b). 
Borasi, R., \& Finnigan, K. (2010). Entrepreneurial attitudes and behaviours that can help prepare successful change-agents in education. The New Educator, 6, 1-29.

Boyd-Dimock, V., \& McGree, K. M. (1995). Leading change from the classroom: Teachers as leaders. Retrieved from: http://www.sedl.org/change/issues/issues44.html

Braun, V., \& Clarke, V. (2006). Using thematic analysis in psychology. Qualitative Research in Psychology, 3, 77-101.

Carlsson, B., Braunerhjelm, P., McKelvey, M., Olofsson, C., Persson, L., \& Ylinenpää, H.

(2013). The evolving domain of entrepreneurship research. Small Business Economics, 41(4), 913-930.

Chand, V. S. (2014). Socio-educational entrepreneurship within the public sector: Leveraging teacher-driven innovations for improvement. In A. W. Wiseman (Ed.), International Educational Innovation and Public Sector Entrepreneurship: International Perspectives on Education and Society (pp. 59-82). Bingley, UK: Emerald Group Publishing.

Chell, E. (1985). The entrepreneurial personality: A few ghosts laid to rest? International Small Business Journal, 3(3), 43-54.

Creswell, J. W., \& Plano Clark, V. L. (2007). Designing and conducting mixed methods research. Thousand Oaks, CA: Sage.

Danielson, C. (2007). The many faces of leadership. Educational Leadership, 65(1), 14-19.

Davis, V. (2009). Influencing positive change: The vital behaviours to turn schools toward success. Teacher Librarian, 37(2), 8-12.

Dickson, P. H., Solomon, G. T., \& Weaver, K. M. (2008). Entrepreneurial selection and success: Does education matter? Journal of Small Business and Enterprise Development, 15(2), 239-258. 
Eisenhardt, K. M., \& Graebner, M. E. (2007). Theory building from cases: Opportunities and challenges. Academy of Management Journal, 50(1), 25-32.

Elliott, R., Fischer, C. T., \& Rennie, D. L. (1999). Evolving guidelines for publication of qualitative research studies in psychology and related fields. British Journal of Clinical Psychology, 38, 215-229.

Ertuna, Z. I., \& Gurel, E. (2011). The moderating role of higher education on entrepreneurship. Education \& Training, 53(5), 387-402.

Fairbanks, C. M., Duffy, G. G., Faircloth, B. S., He, Y., Levin, B., Rohr, J., \& Stein, C. (2010). Beyond knowledge: Exploring why some teachers are more thoughtfully adaptive than others. Journal of Teacher Education, 61(1-2), 161-171.

Foote, C. (2012). Edu-preneurship: Being more than "just a teacher". Retrieved from: http://www.techlearning.com/news/0002/edupreneurship/64921.

Frese, M., Fay, D., Hilburger, T., Leng, K., \& Tag, L. (1997). The concept of personal initiative: Operationalization, reliability, and validity in two German samples. Journal of Organizational \& Occupational Psychology, 70, 139-161.

Fung, H. H., Lai, P., \& Ng, R. (2001). Age differences in social preferences among Taiwanese and Mainland Chinese: The role of perceived time. Psychology and Aging, 16(2), 351356.

Gardner, J. W. (2013). The nature of leadership. In M. Grogan (Ed.), The Jossey-Bass reader on educational leadership (pp. 17-27). San Francisco, CA: Jossey-Bass.

Georgellis, Y., \& Wall, H. (2005). Gender differences in self-employment. International Review of Applied Economics, 19(3), 321-342. 
Gibb, A. A. (1998). Entrepreneurial core capacities, competitiveness and management development in the 21 st century. Durham, UK: DUBS.

Greckhamer, T., \& Koro-Ljungberg, M. (2005). The erosion of a method: Examples from grounded theory. International Journal of Qualitative Studies in Education, 18(6), 729750.

Guth, W. D., \& Ginsberg, A. (1990). Guest editors' introduction: Corporate entrepreneurship. Strategic management journal, 11, 5-15.

Hanson, W. E., Creswell, J. W., Plano Clark, V. L., Petska, K. S., \& Creswell, J. D. (2005). Mixed methods research designs in counseling psychology. Journal of Counseling Psychology, 52(2), 224-235.

Hatak, I., Harms, R., \& Fink, M. (2015). Age, job identification, and entrepreneurial intention. Journal of Managerial Psychology, 30(1), 38-53.

Hayton, J. C., \& Kelley, D. J. (2006). A competency-based framework for promoting corporate entrepreneurship. Human Resource Management, 45(3), 407-427.

Hebert, R. F., \& Link, A. N. (1989). In search of the meaning of entrepreneurship. Small Business Economics, 1(1), 39-49.

Hoekstra, B. (2014). Relating training to job satisfaction: A survey of online faculty members. Journal of Adult Education, 43(1), 1-10.

Katz, J. A. (2003). The chronology and intellectual trajectory of American entrepreneurship education 1876-1999. Journal of Business Venturing, 18, 283-300.

Kautonen, T., Hatak, I., Kibler, E., \& Wainwright, T. (2015). Emergence of entrepreneurial behaviour: The role of age-based self-image. Journal of Economic Psychology, 50, 4151. 
Kelley, D. J., Singer, S., \& Herrington, M. (2012). The global entrepreneurship monitor. 2011 global report. Global Entrepreneurship Research Association. Available from: www.gemconsortium.com.

Kitchel, T., Smith, A. R., Henry, A. L., Robinson, J. S., Lawver, R. G., Park, T. D., \& Schell, A. (2012). Teacher job satisfaction and burnout viewed through social comparisons. Journal of Agricultural Education, 53(1), 21-44.

Landstrom, H. (1999). The roots of entrepreneurship research. The intellectual development of a research field. New England Journal of Entrepreneurship, 1(2) 9-20.

Langowitz, N., \& Minniti, M. (2007). The entrepreneurial propensity of women. Entrepreneurship: Theory and Practice, 31(3), 341-364.

Lewis, P. (2006). The quest for invisibility: Female entrepreneurs and the masculine norm of entrepreneurship. Gender, Work and Organization, 13(5), 453-469.

Maes, J., Leroy, H., \& Sels, L. (2014). Gender differences in entrepreneurial intentions: A TPB multi-group analysis at factor and indicator level. European Management Journal, 32(5), 784-794.

Marlow, S., \& Patton, D. (2005). All credit to men? Entrepreneurship, finance, and gender. Entrepreneurship: Theory and Practice, 29(6), 717-735.

Mueller, S. L., \& Dato-on, M. C. (2013). A cross cultural study of gender-role orientation and entrepreneurial self-efficacy. International Entrepreneurship and Management Journal, $9(1), 1-20$.

Murphy, P. J., Liao, J., \& Welsch, H. P. (2006). A conceptual history of entrepreneurial thought. Journal of Management History, 12(1), 12-35. 
Omer Attali, M., \& Yemini, M. (2016). Initiating consensus: Stakeholders define entrepreneurship in education. Educational Review, 69(2), 140-157.

Onstenk, J. (2003). Entrepreneurship and vocational education. European Educational Research Journal, 2(1), 74-89.

Ortega, L. M., \& Bagnato, V. S. (2015). The practice of innovation at Brazilian public university: The case of the University of Sao Paulo. Brazilian Journal of Science and Technology, 2(6), 1-15.

Petersen, J. L. (2014). For education entrepreneurs, innovation yields high return. Education Next, 14(2), 8-16.

Rauch, A., \& Frese, M. (2000). Psychological approaches to entrepreneurial success: A general model and an overview of findings. International Review of Industrial and Organizational Psychology, 15, 101-142.

Rottinghaus, P. J., Buelow, K. L., Matyja, A., \& Schneider, M. R. (2012). The Career Futures Inventory-Revised: Measuring dimensions of career adaptability. Journal of Career Assessment, 20(2), 123-139.

Rottinghaus, P. J., Day, S. X., \& Borgen, F. H. (2005). The Career Futures Inventory: A measure of career-related adaptability and optimism. Journal of Career Assessment, 13(1), 3-24.

Rudolph, C. W., Lavigne, K. N., \& Zacher, H. (2017). Career adaptability: A meta-analysis of relationships with measures of adaptability, adapting responses, adapting results. Journal of Vocational Behaviour, 98, 17-34.

Sarasvathy, S. D. (2001). Causation and effectuation: Toward a theoretical shift from economic inevitability to entrepreneurial contingency. Academy of Management Review, 26(2), 243-263. 
Sarasvathy, S. D., Dew, N., Velamuri, S. R., \& Venkataraman, S. (2010). Three views of entrepreneurial opportunity. In Z. J. Acs \& D. B. Audretsch (Eds.), Handbook of Entrepreneurship Research (pp. 141-160). New York, NY: Springer US.

Savickas, M. L. (1997). Career adaptability: An integrative construct for life-span, life-space theory. The Career Development Quarterly, 45(3), 247-259.

Savickas, M. L. (2005). The theory and practice of career construction. In S. D. Brown \& R. W. Lent (Eds.), Career development and counseling: Putting research and theory to work (pp. 42-70). Hoboken, NJ: Wiley.

Savickas, M. L., Briddick, W. C., \& Watkins Jr, C. E. (2002). The relation of career maturity to personality type and social adjustment. Journal of Career Assessment, 10(1), 24-49.

Savickas, M. L. \& Porfeli, E. J. (2012). Career Adapt-Abilities Scale: Construction, reliability, and measurement equivalence across 13 countries. Journal of Vocational Behaviour, 80, $661-673$.

Shane, S. \& Venkataraman, S. (2000). The promise of entrepreneurship as a field of research. The Academy of Management Review, 25(1), 217-226.

Song, S., \& Mustafa, M. (2015). Factors impacting on teachers' job satisfaction related to science teaching: A mixed methods study. Science Education International, 26(3), 358375.

Stevenson, H. H. (2004). Intellectual foundations of entrepreneurship. In H. P. Welsch (Ed.), Entrepreneurship: The way ahead (pp. 3-14). New York, NY: Routledge.

Stivers, J., \& Cramer, S. F. (2009). A teacher's guide to change: Understanding, navigating, and leading the process. Thousand Oaks, CA: Corwin. 
Super, D. E., \& Kidd, J. M. (1979). Vocational maturity in adulthood: Toward turning a model into a measure. Journal of Vocational Behaviour, 14, 255-270.

Super, D. E., \& Knasel, E. G. (1979). Specifications for a measure of career adaptability in young adults. Cambridge: National Institute for Career Education and Counseling.

Super, D. E., \& Knasel, E. G. (1981). Career development in adulthood: Some theoretical problems and a possible solution. British Journal of Guidance and Counselling, 9(2), 194-201.

Thorgren, S., Sirén, C., Nordström, C., \& Wincent, J. (2016). Hybrid entrepreneurs' second-step choice: The nonlinear relationship between age and intention to enter full-time entrepreneurship. Journal of Business Venturing Insights, 5, 14-18.

U.S. Department of Education, National Center for Education Statistics. (2016). Digest of Education Statistics, 2015. Retrieved from: https://nces.ed.gov

van Dam, K., Schipper, M., \& Runhaar, P. (2010). Developing a competency-based framework for teachers' entrepreneurial behaviour. Teaching and Teacher Education, 26(4), 965971.

van der Kuip, I., \& Verheul, I. (2003). Early development of entrepreneurial qualities. The role of initial education. Retrieved from: https://www.researchgate.net/profile/Ingrid_Verheul/publication/5012669_Early_Develo pment_of_Entrepreneurial_Qualities_the_Role_of_Initial_Education/links/53eded890cf2 6b9b7dc635e1.pdf

Webber, C. F., \& Scott, S. (2008). Entrepreneurship and educational leadership development: Canadian and Australian perspectives. International Electronic Journal for Leadership in Learning, 12(14), 1-15. 
Weber, P., \& Schaper, M. (2004). Understanding the grey entrepreneur. Journal of Enterprising Culture, 12(2), 147-164.

Zhang, Z., Zyphur, M. J., Narayanan, J., Arvey, R. D., Chaturvedi, S., Avolio, B. J., ... Larsson, G. (2009). The genetic basis of entrepreneurship: Effects of gender and personality. Organizational Behaviour and Human Decision Processes, 110(2), 93-107. 
Table 2

Teaching adaptations of both groups

\begin{tabular}{|c|c|c|}
\hline \multirow[t]{2}{*}{ Teaching Adaptations } & \multicolumn{2}{|c|}{ Representative Quotes } \\
\hline & Top $10 \%$ & Bottom $10 \%$ \\
\hline $\begin{array}{l}\text { Alignment to policies, } \\
\text { standards and regulations }\end{array}$ & $\begin{array}{l}\text { "Read, reread, and studied the District Provided Teacher appraisal } \\
\text { plan proposed by the district and agreed upon by our union" }\end{array}$ & - \\
\hline Assessment & $\begin{array}{l}\text { "Alternative assessment techniques such as gallery walks, labs as } \\
\text { tests, presentations, lab design, etc" }\end{array}$ & $\begin{array}{l}\text { "To hold students more accountable for their practice, I } \\
\text { implemented concept quizzes" }\end{array}$ \\
\hline Behaviour management & - & $\begin{array}{l}\text { "When classes are not behaving well, I allow them to work } \\
\text { on their own rather than in groups" }\end{array}$ \\
\hline Career changes & "Changed career settings" & "I adapted by taking on a new grade level" \\
\hline $\begin{array}{l}\text { Differentiating } \\
\text { instruction }\end{array}$ & - & $\begin{array}{l}\text { "Implementing higher thinking questions for students who } \\
\text { are more advanced" }\end{array}$ \\
\hline Impacting curriculum & "Created a curriculum course to address transition needs" & "Developed curriculum for a new course" \\
\hline Lesson plan & - & "I have changed plans when it is not working well" \\
\hline Peer collaboration & $\begin{array}{l}\text { "Coordinated with colleagues to meet the challenge so all were } \\
\text { working toward a goal" }\end{array}$ & "Asked other teachers to give input to lessons" \\
\hline $\begin{array}{l}\text { Professional training and } \\
\text { knowledge acquisition }\end{array}$ & $\begin{array}{l}\text { "I kept training myself in my field by attending professional } \\
\text { development workshops" }\end{array}$ & - \\
\hline $\begin{array}{l}\text { Reducing expectations } \\
\text { for lower achieving } \\
\text { students }\end{array}$ & - & $\begin{array}{l}\text { "Allowed less-skilled students succeed without meeting } \\
\text { certain requirements" }\end{array}$ \\
\hline Student collaboration & "A lot of group discussion and collaboration" & - \\
\hline Teaching strategies & "Changed lab procedure when material ran out" & "I have changed the amount of homework I give" \\
\hline Technology use & "Use of iPads and technology" & "Pilot 1:1 initiative with Chrome books" \\
\hline Time management & $\begin{array}{l}\text { "My team adapted our schedule to allow for more concentrated time } \\
\text { in science" }\end{array}$ & $\begin{array}{l}\text { "Teaching in an abbreviated period - adjusting lesson } \\
\text { planning and pacing" }\end{array}$ \\
\hline
\end{tabular}


Table 3

Drivers to teaching adaptations of both groups

\begin{tabular}{|c|c|c|}
\hline \multirow[t]{2}{*}{ Adaptation Drivers } & \multicolumn{2}{|c|}{ Representative Quotes } \\
\hline & Top $10 \%$ & Bottom $10 \%$ \\
\hline \multicolumn{3}{|l|}{ Student focus } \\
\hline a) Achieve student success & "Motivate students to achieve their potential" & "For the success of my students" \\
\hline b) Facilitate learning & $\begin{array}{l}\text { "Help students improve in making meaning by reading and } \\
\text { writing" }\end{array}$ & $\begin{array}{l}\text { "I was trying to improve on my students } \\
\text { knowledge of chemistry nomenclature" }\end{array}$ \\
\hline c) Increase student engagement & "Student engagement" & $\begin{array}{l}\text { "Increase student engagement and } \\
\text { participation" }\end{array}$ \\
\hline d) Meet students' needs & "Meet the needs of students" & "To better reach struggling students" \\
\hline \multicolumn{3}{|l|}{ Teacher focus } \\
\hline a) Collaborate with peers & "To work collaboratively with a colleague" & - \\
\hline b) Develop teachers professionally & "Improve my teaching and ability as well as broaden my learning" & - \\
\hline c) Personal reasons & - & "To do what is best for my family" \\
\hline e) Teachers' experience and training & - & $\begin{array}{l}\text { "I changed because I was introduced to this } \\
\text { within summer courses and listened to the } \\
\text { success that other teachers found with it" }\end{array}$ \\
\hline \multicolumn{3}{|l|}{ Practice focus } \\
\hline a) Behaviour management & - & "Students were not behaving well" \\
\hline b) Use data to drive instruction & $\begin{array}{l}\text { "Using data from my tests point to my students' weaknesses on } \\
\text { mastery of objectives" }\end{array}$ & - \\
\hline \multicolumn{3}{|l|}{ School focus } \\
\hline $\begin{array}{l}\text { a) Address differences with } \\
\text { administration }\end{array}$ & "Didn't see eye to eye with administration" & - \\
\hline b) Manage limited time & "To maximize class time" & $\begin{array}{l}\text { "To fit the entire curriculum when time was } \\
\text { constrained" }\end{array}$ \\
\hline c) Reacting to imposed decisions & - & "Told to by administration" \\
\hline d) Respond to lack of resources & $\begin{array}{l}\text { "Raised fund to support curriculum change through grant funding } \\
\text { and material sales" }\end{array}$ & - \\
\hline
\end{tabular}




\begin{tabular}{|c|l|l|}
\hline & & \\
\hline Policy focus & & \\
\hline a) Adhere to plans, goals, and standards & "Implementation of department goals for 2016-2017" & - \\
\hline
\end{tabular}


